\title{
The role of E-leadership in ICT utilization: a project management perspective
}

\author{
XiaoHu Wang ${ }^{1} \cdot$ XiaNan Wei $^{2} \cdot$ Montgomery Van Wart $^{3} \cdot$ Alma McCarthy $^{4} \cdot$ Cheol Liu $^{5} \cdot$ Soonhee Kim ${ }^{5}$. \\ David H. Ready ${ }^{6}$
}

Accepted: 29 December 2021

(c) The Author(s), under exclusive licence to Springer Science+Business Media, LLC, part of Springer Nature 2022

\begin{abstract}
Covid 19 presents a great challenge and opportunity for remote working, highlighting the need for electronically-mediated leadership in team tasks and performance. What is the role of leadership in improving utilization of information communication technologies (ICTs) in teamwork? Framed within the e-leadership and project management literature and employing a longitudinal field observation method over 8 months that involves 52 subjects and 172 observations, this study finds that (1) first, strong leaders employ a consistent and high-level use of ICTs throughout the whole process of group work, especially at the planning and closing stages of a project. (2) Second, strong leaders alternate the use of various ICTs to match specific tasks at different phases of the project. Two media platforms - team discussion forum and document sharing — stand out as the most important for strong leaders to build trust and execute tasks. (3) Finally, in a project management setting with a group of transient members with clearly-defined tasks and time-sensitive responsibilities, trust-building is a continual and highly significant leadership responsibility that precedes other leadership responsibilities. Trust is built largely through alternating the use of two rich ICT media (discussion forum and instant messaging) with two lean ICT media (document sharing and presentation display). These findings highlight a significant role of e-leadership in organizations which see the emergence of ICTs especially during crises like Covid 19.
\end{abstract}

Keywords E-leadership $\cdot$ ICT utilization $\cdot$ Team management $\cdot$ Project management

\section{Introduction}

Institutional support has been identified as a key factor facilitating the use of information communication technologies (ICTs) [1-3]. However, little is known about the role of

XiaoHu Wang

xwang65@cityu.edu.hk

XiaNan Wei

weixianan@ruc.edu.cn

Montgomery Van Wart

MVanWart@csusb.edu

Alma McCarthy

alma.mccarthy@nuigalway.ie

Cheol Liu

cliu@kdischool.ac.kr

Soonhee Kim

soonheekim@kdischool.ac.kr

David H. Ready

david.ready@palmspringsca.gov organizational leaders in ICT use, especially at project management settings where time-sensitive goals required of transient team members post challenges for leaders. This research examines the role of leadership in ICT utilization in completing work responsibilities in a teamwork setting. We ask the

1 Department of Public Policy, City University of Hong Kong, Hong Kong, China

2 School of Public Administration and Policy, Renmin University of China, Beijing, China

3 College of Business and Public Administration, California State University, San Bernardino, USA

4 J. E. Cairnes School of Business and Economics, National University of Ireland, Galway, Ireland

5 School of Public Policy and Management, KDI, Sejong, South Korea

6 City of Palm Springs, USA 
research questions: When and how do leaders utilize (and integrate) media including ICTs at the team level? What is the relationship between leadership and ICT utilization? How may leadership influence group outcomes such as performance, satisfaction, and learning?

The communication and teamwork literatures have investigated the overall role of ICTs in individual and group tasks (e.g., [4-8]). Nevertheless, little is known about the concrete relationship between leadership and specific types of ICTs, especially at the team level [9]. Covid 19 increases the urgency to study this relationship and provide lessons for leaders who manage team-level tasks for members working at home or at distance. This research explores this complex relationship, and contributes to understanding the role of leadership in ICT utilization and team performance.

\section{Theoretical background}

\subsection{Teamwork settings}

There are many ways to classify work-related teams [10-12]. They can be variously classified as: work teams or improvement/advisory teams; short term or long term; functional, cross-functional, or self-managing; project (performing) teams or advisory teams; and co-located or virtual. Here we focus on project (management) teams which are a type of work team, short term, and self-managing (but they are frequently cross-functional in work settings). They can be either co-located or virtual. While all work-related teams share some degree of commonality, their purpose and structures must be considered in making generalizations [11].

Project management is the practice of initiating, planning, executing, controlling, and closing the work of a team to achieve specific goals and meet specific success criteria at the specified time [13]. A project is a temporary multistep process designed to produce a unique product, service, or result with a defined beginning and end (usually timeconstrained, and often constrained by funding or staffing) undertaken to meet unique goals and objectives, typically to bring about beneficial change or added value [14]. The temporary nature of projects stands in contrast to business as usual, standard operations which are repetitive, permanent, or semi-permanent functional activities to produce products or services. In practice, the management of such distinct production approaches-focusing on problems or new/customized work products-requires the development of distinct technical skills and management strategies.

\subsection{Effectiveness and leadership in work-related teams}

There is a vast and still growing literature on the effectiveness in work teams. One of the most highly cited is
Katzenbach and Smith [15] who define teams as "a small number of people with complementary skills who are committed to a common purpose, performance goals, and approach for which they hold themselves mutually accountable." For Katzenbach and Smith, some of the necessary elements of good team leadership include: focusing on the relevant purpose, goals and approach; building commitment and confidence among the members; ensuring the mix and level of skills; and creating opportunities for others.

Although their popular work has not been rigorously tested by academics, academic studies do generally support their findings. Fussell et al. [16] found that basic communication coordination predicted performance outcomes, but communication overload was insignificant. Druskat and Kayes [17] found that performance was based not only on proactive problem solving and maintaining group discipline, but interpersonal understanding as well. Guenter et al. [18] found that trust is important for team performance, but basic coordination is more important. While work teams are often urged to stay on task and be accountable and businesslike, much literature across disciplines has long maintained that driving relationship behavior out of work settings is ultimately dysfunctional (e.g., [19]). An example of this in team research is Purvanova [20] whose study links members' sense of "feeling known" as a direct predictor of positive outcomes. In investigating transformational leadership in teams, Lehmann-Willenbrock et al. [21] emphasize the need for solution-focused behavior to transform (address) problems, both by inclusion of their own ideas and the ideas of others, while discouraging dysfunctional behaviors. Richter, Dawson, and West [22] found that "teamwork has a significant but small positive relationship with both performance and staff attitudes." In an overall review of teamwork, Salas, et al. [23] had findings similar to Katzenbach and Smith [15] regarding teamwork, but added the importance of human resources (HR) practices to encourage good team cultures. Lee et al. [24] noted that HR factors such as technical staff have a positive and significant relationship with team performance. The technical aspects of team skills generally are covered in the team training literature (e.g., [25]). Training not only increases productivity, it also reduces the subjective sense of workload [26]. Trust is much discussed in the management literature and that is true in the teamwork literature as well. In some cases, such as action teams in which the stakes and stress levels are high, trust becomes the most important element for continued success [27]. However, the study of effective small group communication such as media type has been limited, especially when taking account of the longitudinal aspects involved in longer-term projects. A rare exception is Erhardt, et al. [28] who explore the affordances of email for team learning over time, finding three nonlinear cycles of knowledge sharing, co-operation, and constructive conflict. 
An important aspect of project management today is the degree to which it relies on virtual media, and how the use of virtual media affects various outcomes such as performance and satisfaction. McLeod [29] reports that decision making in virtual settings was best when some team members were co-located but others were distributed virtually, requiring compensatory effort. Similarly, when examining the degree of virtuality that improves information sharing, high levels of virtuality hinder it [5]. In an overview article, Bergiel, Bergiel, \& Balsmeier [30] find the factors required in a successful virtual team are trust, communication, leadership, goals, and technology. In examining the debates on the necessity of using rich media (e.g., face-to-face meetings) versus lean media (e.g., email), or the communication intensity of media, Straube et al. [31] found it was a compensatory balancing of these factors that was most important. Supportive of this finding were studies that found that only occasional face-to-face meetings are necessary in research teams [32], and that entirely chat-based teams could produce the same task performance, but cohesion was significantly less in a setting relying solely on a lean medium [33, 34]. Research also suggests virtual teams also need more training and members who have high levels of self-efficacy [4, $35,36]$.

\subsection{E-leadership and ICT utilizations in project management}

The primary challenge of project management is to achieve all project goals within the given constraints. This information is usually described in project documentation created at the beginning of the development process. The primary constraints are scope, time, quality, and budget. The secondary, more ambitious challenge is to optimize the allocation of necessary inputs and apply them to meet pre-defined objectives. The object of project management is to produce a complete project which complies with the objectives. If the project management objectives are ill-defined or too tightly prescribed limiting creativity, they may have a detrimental effect on decision making [37].

An effective leader can take advantage of ICTs to facilitate the project management process and overcome these challenges. Projects can be seen as complex group efforts having a limited, continuing group of individuals, requiring numerous communications that may vary over time [38], in which both effectiveness (meeting goals) and efficiency (doing so with the minimum time and effort) must be balanced $[28,39]$. Of interest to this study is observing leadership activities utilizing specific ICTs over time in project initiating, planning and design, executing and monitoring, and closing in order to generate perceived benefits.

As projects involve distinctive phases over time, some leadership theories that articulate communication with evolving longitudinal parameters in the leadership/ICT relationship are also useful [40, 41]. For example, ICT succession theory examines the numerous situations in which different ICTs are used in strategic chronological configurations by leaders. Perhaps its most important hypothesis is that an ICT strategy over time generally needs to involve complementary modalities to enhance effectiveness, in an evolving series of events. Stephens and colleagues partially addressed this issue with their examination of the use of ICTs in sequences over time [8, 42].

\section{Research model development}

\subsection{Project management}

We use a longitudinal field study over an 8 months period with 4 data collection time points and employ multiple data collection methods in a project management setting designed for process/decision complexity to answer our research questions and provide queries for future research as recommended by Ramos-Villagrasa, et al. [43]. We focus on the group tasks and responsibilities of the leader because of the well-documented effects of leadership on process efficacy and team performance $[44,45]$ and the importance of communication on leadership. Although individual or sociodemographic traits are important in their own right [31], we do not focus on this aspect in this relatively homogeneous context in examining the relationship between leadership and ICT utilization.

We select a project management setting because the conditions and constraints of such a setting-temporarilyassembled personnel, limited timelines, a complex designated task in clearly-defined phases of project completion-create salient and ideal situations for more complex and critical leadership communication, especially e-communication, where leadership behaviors and activities can be observed [38]. Observing single communications or duties is primarily about distinguishing simple operational tasks, and rarely captures the more complex functions which define leadership in small groups [46]. Observing leadership in technology utilization-for decision making, complex social interactions, leading change-requires an intensive setting where ICTs are utilized [47-50]. Project management provides these situational characteristics [51]. Moreover, different from repeated routine organizational tasks, the distinctive phases in project management facilitate the process of longitudinal observations [11].

\subsection{E-leadership}

This research adopts a concept of e-leadership developed by Van Wart et al. [52, 53] and Roman et al. [54] that 
Table 1 Definitions of the major elements of the SEC model

\begin{tabular}{ll}
\hline E- competency & Description \\
\hline $\begin{array}{l}\text { E-communication (basic } \\
\text { communication and task } \\
\text { competence) }\end{array}$ & $\begin{array}{c}\text { The leader has the ability to communicate via ICTs in a manner that is clear and organized, avoids errors and } \\
\text { miscommunication, and is not excessive or detrimental to performance }\end{array}$ \\
$\begin{array}{l}\text { E-social (relationship building) } \\
\text { E-change }\end{array}$ & $\begin{array}{c}\text { The leader has the ability to create a positive work environment and to improve communication and collabora- } \\
\text { tion through a variety of virtual communication methods } \\
\text { The leader has the ability to manage change initiatives effectively through ICTs } \\
\text { E-team }\end{array}$ \\
$\begin{array}{l}\text { The leader has the ability to build, motivate, recognize, and hold accountable teams in virtual environments } \\
\text { The leader is technologically savvy and remains current on relevant ICT developments and ICT security-related } \\
\text { concerns } \\
\text { The leader has the ability when using ICTs to create a sense of trust by being perceived as honest, consistent, } \\
\text { and fair }\end{array}$ \\
\hline
\end{tabular}

emphasizes a leader's virtual communication skills and specifies six unique dimensions. That is: E-leadership is a set of information communication technologies mediating social influence processes intended to change attitudes, feelings, thinking, behavior, and performance, which are based on the ability to communicate clearly and appropriately, provide adequate social interaction, inspire and manage change, build and hold teams accountable, demonstrate technological knowledge related to ICTs, and develop a sense of trust in virtual environments.

The concept consists of six main interrelated digital competencies: e-communication, e-social skill, e-change management, e-team skills, e-tech savvy, and e-trustworthiness. It is conceptualized as a multi-dimensional, integrated, and comprehensive concept in which one aspect is associated with others. It mirrors the types of communication competencies that one expects in traditional communication uses, with the exception of e-tech which is an added dimension of competence required to use virtual media effectively [54]. See Table 1 for definitions used in the six e-competency model (SEC).

It should be noted that e-leadership activities are seen in both physical and virtual workplaces, though the adoption of ICTs is clearly more prevalent in latter settings (like during Covid 19). Also important is that e-leadership is not about the replacement or substitution of traditional media (i.e., face-to-face meetings, printed documents, traditional mail, etc.) with virtual communication tools (i.e., email, videoconferencing, social media, instant messaging, etc.) per se. It is about the integrated use of traditional and virtual media in order to promote efficiency and effectiveness of the many goals of leaders related to tasks, people, and organizational outcomes [55]. The importance of technology for leadership and communication patterns has long been recognized [56, 57]. However, with the digital revolution, and the ubiquity and power of ICTs in leaders' lives [58], the study of the integration of virtual communication tools (e-leadership) has become a critical research concern.

In this research, we propose the relationship between leadership and new virtual communication media can be understood in two perspectives with: (a) leadership driving ICTs, and (b) ICTs impacting leadership, in a feedback loop in cyclical fashion as described in Fig. 1.

In this framework, team members often (but not always) meet face-to-face to start off the entire project, and subsequently, the leader takes action to adopt additional ICTs to complete phase 1. Individual-level factors may influence initial ICT adoptions. After specific ICTs are adopted, virtual communications are developed and patterns of ICT utilization and overall leadership communication patterns emerge. After phase 1, ICT-enhanced leadership leads to adjustments in ICTs to assign new responsibilities and solve problems, which is also based on earlier experience with ICTs. Based on the effective use of ICTs (integrated with traditional media use) over the phases, we expect an impact on overall project outcomes, though the outcomes can also be affected by other individual- or team-level variables such as group members' academic competencies, extraneous events, interfering subgroup faultlines, etc. It should be noted that while we specify institutional performance as outcomes, outcomes can also include relationship comfort while working together, member satisfaction, member learning, etc.

\section{Data collection method}

\subsection{Research design and data}

We design a field study involving multiple observations in 4 phases of project management. Field research is ideal for observing social processes over time [59]. In this study, the subjects are college students enrolled in 
Fig. 1 The relationships between leadership communication and ICT utilization in project management

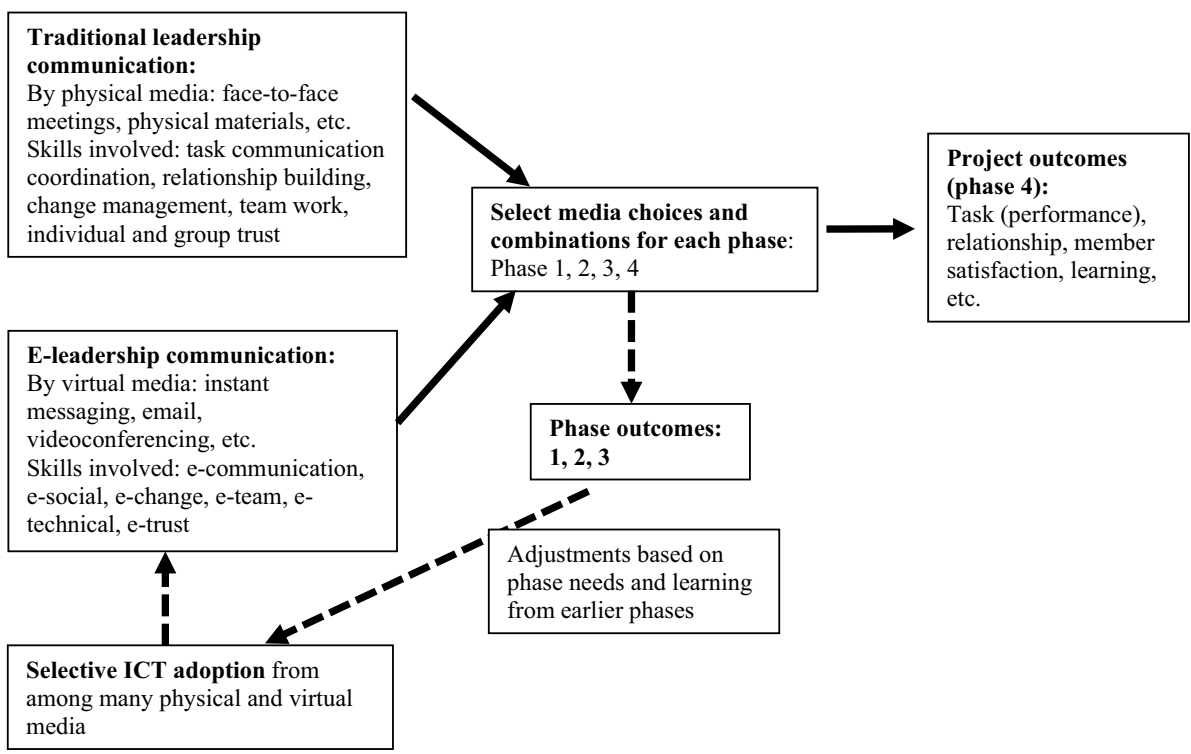

a capstone project at a public university in Hong Kong. College students in public policy/management programs taking a capstone course in a public management master program were recruited for the study in which team leaders were analyzed for their leadership behaviors. ICT utilization patterns were also observed for each team. The researchers played a neutral and relatively unobtrusive role that limited influence on the participating subjects as much as possible.

Subjects were divided by the instructor into groups of 4 to 5 members wherein a team leader was self-selected in each group [60]. Teams were tasked to complete academic projects which would be graded at the end of study period. ICT utilization training sessions were provided by technical staff of the university on how to use Canvas - the ICT platform for course management offered at the university, with a focus on multiple Canvas functions such as group discussion forum, document sharing, and visual conferencing. The activities and performance of the groups were carefully observed 4 times with a survey instrument. A research period of 8 months allowed observation of the evolving process of leadership and ICT patterns during the study. Qualitative data on members' reflections on the process were also collected in their reflective essays. Some group members were also interviewed.

52 subjects (students) were assigned to 12 teams. The data were collected through 4 phases of project development. The first phase (Initiating phase) was completed in February 2019 with 50 responses; the second phase (Planning phase) was completed in early April 2019 with
44 responses; the third phase (Execution phase) was conducted in late May 2019 with 40 responses and the last phase (Closing phase) was completed in July 2019 with 42 responses. The data are tracked to create a panel data base with $(50+44+40+42=) 176$ valid observations.

\subsection{Measurement}

Appendix A provides a detailed measurement matrix of ICT utilization, e-leadership, team dynamics, and team outcomes. In measuring ICT utilization, measures were developed to assess the frequencies of the 10 most-used media including email, videoconferencing, telephone, instant messaging, social media, team platforms, document sharing, and presentation displays, as well as the traditional methods of face-to-face and hard-copy exchange. Communication intervals were measured by frequency patterns as defined in Appendix A and noted in Table 2. Because communications could happen not just between team leaders and members but among team members themselves, all subjects were requested to answer these ICT questions to gauge the level of ICT utilization for a group.

The measurement of e-leadership centers on a leader's abilities (competencies) in an ICT-mediated process to change behaviors and performance [53]. We used 69 survey items developed in the previous literature [54] that classify e-leadership into the six dimensions of e-communication, e-team, e-trust, e-social, e-tech, and e-change (see Table 1). These items were included in a survey instrument that was delivered to the subjects 4 times, each time with a different context that specified potential project management issues at 
Table 2 Media utilization patterns

\begin{tabular}{llllll}
\hline Project phases type of media & Initiating & Planning & Execution & Closing & Rank change $^{1}$ \\
\hline Instant messaging & 5.48 & 4.75 & 4.38 & 4.83 & $1-1-1-1$ \\
Team discussion platform & 5.18 & 4.43 & 4.10 & 4.36 & $2-2-2-2$ \\
Document sharing & 4.54 & 4.20 & 3.60 & 4.24 & $3-3-3-3$ \\
Face-to-face & 3.92 & 3.39 & 3.15 & 3.12 & $4-4-4-5$ \\
Presentation display & 3.14 & 3.25 & 2.48 & 3.21 & $5-5-5-4$ \\
Hard copies of documents & 2.78 & 2.57 & 2.28 & 2.6 & $6-7-6-7$ \\
Email & 2.70 & 2.18 & 2.23 & 2.14 & $7-9-8-10$ \\
Social media & 2.26 & 2.70 & 2.05 & 2.31 & $8-6-9-9$ \\
Telephone & 2.20 & 2.2 & 2.25 & 2.63 & $9-8-7-6$ \\
Video conferencing & 2.10 & 1.93 & 1.80 & 2.36 & $10-10-10-8$ \\
\hline
\end{tabular}

Presented are the mean scores with $1=$ Never; $2=$ less than 1 times weekly; $3=1$ to 2 times weekly; $4=3$ to 4 times weekly; $5=5$ to 6 times weekly; $6=$ more than 6 times weekly. ${ }^{1} 1$ is the highest rank, 6 is the lowest rank that stage. A five-point scale was used for these items, with 5 being "strongly agree" with the statement and 1 "strongly disagree." Measurement details including item examples and reliability test results can be seen in Appendix A. This way of measuring e-leadership is partially built on the ICT succession theory that indicates using multiple, complementary ICT modalities successively improves message influence [8, 39, 42], and Van Wart's [61] task-oriented behaviors used in successive project processes of initiating, planning, executing (monitoring), and closing down a project (see Appendix $\mathrm{B}$ for more information on project phases).

An intermediate process measure of "team dynamics" was also developed to assess. In this research, we conducted a peer review to understand the group dynamics within 12 teams on their operations and management. The result of this review was a process measure of team dynamics that assesses the potential impact of leadership on the project management process as specified in the literature [45] (see Appendix A for measurement detail). This variable reflects the highly interactive process often observed in project management. Project outcomes were also measured by project grades evaluated and assigned by two professors, independently. Measures were taken to protect subjects' confidentiality so no name was identified in the study, and only grouplevel or class-level statistics are presented.

\section{Findings}

This section first presents the findings on ICT utilization patterns, followed by key results on how leadership may influence such patterns. Table 2 shows ten media and their pattern changes during 4 project stages. Instant messaging (largely Wechat and WhatsApp), team discussion platform (Canvas), and document sharing (Google Drive and Dropbox) are the 3 most frequently-used media in all phases. Interestingly, the face-to-face medium is only 4th in usage, which is a relatively static position through all stages. All 4 top media utilization rates declined in the 2nd phase (planning) and 3rd phase (execution). Three of the four increase again in the closing stage except face-to-face, contrary to our expectations. A technique integral to the project itself, presentation display, switched positions with face-to-face in the final stage.

While face-to-face is a robust medium often desirable to users because of its "richness," it is often inconvenient in its requirements for scheduling and travel, and inflexible in timing, especially during emergencies (like Covid 19) when in-person meetings are restricted. While participants clearly valued face-to-face meetings, they used them more sparingly, and replaced them with other less-rich media such as frequent instant messaging or shared chat methods. As one respondent said in the reflective essay, "it was a difficult task to finish the project on time through face-to-face meetings, so we created a group chat to replace some face-to-face communication."

Groups used combinations of virtual messages to achieve richness by the rapidity of response (instant messaging), the convenience of responding after consideration with clear, documented answers (team discussion platforms), and the sharing of actual project materials in real time (document sharing). The use of multiple virtual media with frequent interactions allowed participants to shift from occasional synchronous face-to-face meetings with hard copy exchanges and review to asynchronous virtual settings. As one subject noted in the essay, "we tried to use different kinds of approaches to facilitate the communication and the 
Table 3 E-leadership and media utilization

\begin{tabular}{lllc}
\hline & \multicolumn{2}{l}{ Overall } & \\
\cline { 2 - 4 } & $\begin{array}{l}\text { Stronger } \\
\text { e-leadership } \\
\text { group }\end{array}$ & $\begin{array}{l}\text { Weaker } \\
\text { e-leadership } \\
\text { Group }\end{array}$ & Difference \\
\hline Instant Messaging & 4.99 & 4.59 & 0.40 \\
Team Discussion Forum & 4.81 & 4.06 & $0.75^{*[0.073]}$ \\
Document Sharing & 4.44 & 3.74 & $0.70^{* *[0.023]}$ \\
Face to Face & 3.32 & 3.41 & -0.09 \\
Presentation Display & 3.09 & 2.87 & 0.22 \\
Hard Copies of Docu- & 2.58 & 2.44 & 0.14 \\
$\quad$ ments & 2.22 & 2.33 & -0.11 \\
Emails & 2.12 & 2.49 & -0.37 \\
Social media & 2.36 & 2.19 & 0.17 \\
Telephone & 2.18 & 1.9 & 0.28 \\
Video Conferencing & & & \\
\hline
\end{tabular}

(1) Presented are the mean scores as noted in Table 2; six is high. (2) In brackets are values of statistical significance highlighted with ${ }^{*} p<.1 ; * * p<.05$; *** $p<.01$ for the $t$-test for two independent samples with two-tailed probability. (3) $n=6$ for both the stronger and weaker e-leadership groups

project work. We shared findings and information and created a group chat in WhatsApp as a communication channel. By using Google Drive, we accessed and shared group work progress easily."

It should also be noted that lesser-used media in this case study reflect an array of substitutions, redundancy, and unique factors. Email was largely substituted by the similar functionality of the team discussion platform, as was the use of social media. Nonetheless, these other media were occasionally used and provided useful redundancy. Telephone was used sparingly because it was largely a one-to-one medium, but again, it provided redundancy and greater richness when text messages were insufficient and team platform messages were too slow. Because of its small size, videoconferencing use (potentially a rich and more convenient medium than face-to-face) in Hong Kong lagged many other places, and was not a supported technology of the university at the time of research.

Finding 1: Stronger e-leadership demonstrates a relatively higher-level use of multiple ICTs (especially team discussion forum and document sharing), selective use of traditional media, and use of combinations of media to achieve communication richness.

Teams with a greater level of e-leadership tend to use more media as well. By an overall e-leadership index that includes all e-leadership items in this study (see Appendix A), we classified the top 6 of the 12 study teams as stronger e-leadership teams and the last 6 as weaker e-leadership teams. Table 3 shows their media use in all project phases combined. Stronger e-leadership teams use various virtual media more frequently than the weaker groups. The use of team discussion forum and document sharing-2 complementary tools for effective communication (i.e., forums for clear and recorded discussions followed up by documents sharing) - is particularly salient among stronger e-leadership groups. For example, the use of team discussion forum (mean score $=4.81$ ) was close to 5 times a week in stronger e-leadership groups, significantly greater than that of weaker groups (4.06) which is close to 4 times weekly. The difference is statistically significant at the 10 percent level. On the contrary, there is little difference in the use of more traditional media between stronger and weaker e-leadership teams (email, face-to-face, telephone, hard copies etc.).

The findings suggest the potential impact of e-leadership on ICT utilization pattern in virtual workplaces. Stronger team leaders have a greater use of multiple ICTs, supplemented by selective use of traditional media, to achieve communication richness. Feedback from students indicates that team leaders play a pivotal role in initiating communications with ICTs. As one team member said, "our group captain encouraged us to try a variety of means and help us to brainstorm. Every time we got the feedback from the professor, he promptly organized meetings and discussed our research progress."

Though the existing research shows an increase in ICT adoption in virtual settings which have become increasingly popular especially during Covid 19 [62, 63], the ICT adoption patterns and their causes (including the role of leadership) in these settings have not been fully discovered and understood, though one recent study does find that the significant role of tech-savvy leaders in building virtual teams in leadership effectiveness [54]. This finding suggests that organizational leaders can produce effective institutional outcomes by promoting a higher-level adoption of multiple ICTs with alternating uses of rich media (such as discussion forum) and lean media (such as document sharing) in virtual settings to replace face-to-face communication (rich media) and printed documents (lean media) in physical work settings. Indeed, though there has been little research so far to compare the leadership role in ICT usage in traditional physical workplaces and virtual workplaces, there is an understanding that leadership in virtual settings has certain unique characteristics that distinguish it from leadership in traditional physical settings [64].

Finding 2: Stronger e-leadership teams use ICT more consistently, compared to weaker e-leadership teams which start at about the same ICT level as the stronger e-leadership teams, but finish much weaker at the end. Stronger e-leaders 
Table 4 E-leadership and media use by phase

\begin{tabular}{|c|c|c|c|c|c|c|}
\hline & \multicolumn{3}{|l|}{ Initiating } & \multicolumn{3}{|l|}{ Planning } \\
\hline & $\begin{array}{l}\text { Stronger E-leader- } \\
\text { ship }\end{array}$ & $\begin{array}{l}\text { Weaker E-lead- } \\
\text { ership }\end{array}$ & Difference & $\begin{array}{l}\text { Stronger E-leader- } \\
\text { ship }\end{array}$ & $\begin{array}{l}\text { Weaker E-lead- } \\
\text { ership }\end{array}$ & Difference \\
\hline Instant Messaging & 5.38 & 5.55 & -0.17 & 5.17 & 4.11 & $1.06^{*[0.070]}$ \\
\hline Team Discussion Forum & 5.15 & 5.21 & -0.06 & 4.83 & 3.76 & $1.07 *[0.064]$ \\
\hline Document Sharing & 4.48 & 4.61 & -0.13 & 4.69 & 3.53 & $1.16^{* * *[0.002]}$ \\
\hline Face to Face & 3.41 & 4.55 & $-1.14 * *[0.025]$ & 3.57 & 2.97 & 0.60 \\
\hline Presentation Display & 3.00 & 3.35 & -0.35 & 3.46 & 2.96 & 0.50 \\
\hline $\begin{array}{l}\text { Hard Copies of Docu- } \\
\text { ments }\end{array}$ & 2.96 & 2.78 & 0.18 & 2.90 & 2.00 & $0.90 * *[0.042]$ \\
\hline Emails & 2.86 & 2.58 & 0.28 & 2.22 & 1.96 & 0.26 \\
\hline Social Media & 2.19 & 2.51 & -0.32 & 2.95 & 2.27 & 0.68 \\
\hline Telephone & 1.99 & 2.53 & -0.54 & 2.33 & 1.82 & 0.51 \\
\hline Video Conferencing & $\begin{array}{l}2.15 \\
\text { Execution }\end{array}$ & 2.18 & -0.03 & $\begin{array}{l}2.20 \\
\text { Closing }\end{array}$ & 1.68 & 0.52 \\
\hline Instant Messaging & 4.75 & 3.96 & 0.79 & 5.08 & 4.33 & 0.75 \\
\hline Team Discussion Forum & 4.40 & 3.78 & 0.62 & 4.94 & 3.42 & $1.52 * *[0.038]$ \\
\hline Document Sharing & 3.93 & 3.24 & 0.69 & 4.58 & 3.68 & $0.90 *[0.078]$ \\
\hline Face to Face & 3.22 & 3.06 & 0.16 & 3.22 & 2.92 & 0.30 \\
\hline Presentation Display & 2.5 & 2.4 & 0.10 & 3.57 & 2.63 & 0.94 \\
\hline $\begin{array}{l}\text { Hard Copies of Docu- } \\
\text { ments }\end{array}$ & 2.40 & 2.07 & 0.33 & 3.02 & 1.94 & $1.08 * *[0.039]$ \\
\hline Emails & 2.28 & 2.17 & 0.11 & 2.23 & 1.9 & 0.33 \\
\hline Social Media & 2.25 & 1.71 & 0.54 & 2.06 & 2.48 & -0.42 \\
\hline Telephone & 2.28 & 2.14 & 0.14 & 2.65 & 2.43 & 0.22 \\
\hline Video Conferencing & 1.8 & 1.71 & 0.09 & 2.57 & 2.03 & 0.54 \\
\hline
\end{tabular}

(1) Presented are the mean scores as noted in Table 2; six is high. (2) In brackets are the statistical significant values highlighted with $* p<.1$; $* *$ $p<.05 ; * * * p<.01$ for the t-test for two independent samples with two-tailed probability. (3) $n=6$ for both the stronger and weaker e-leadership groups

know how to maintain contacts and accommodate tasksespecially at the planning and closing phases, alternating various ICTs to match specific requirements at different phases.

Table 4 compares the media use patterns of stronger and weaker e-leadership teams in project phases. Both groups have relatively high usage of all media at the initiating phase (see Appendix B for tasks in various phases). Weaker e-leadership teams initially communicate slightly more in all categories except hard copies and emails. Weaker e-leadership groups have significantly more face-to-face communications likely because some weaker groups have harder time to decide on the topics of their projects. At least one weaker team changed its leader at this stage. One member complained about the difficulty in communication in finding a topic and hinted about the team leader's inability to balance "every groupmates' interests".

When the projects move into the next phase (the planning stage), the communication of the weaker e-leadership groups fall off in all categories, whereas stronger e-leadership groups maintain a stable communication level. Stronger e-leadership groups do 2 things that distinguish themselves from weaker groups when moving into the planning stage from the initiating phase. First, they increase the use of more traditional media such as face-to-face (3.41 to 3.57), presentation display (from 3.00 to 3.46 ) and telephone (from 1.99 to 2.33). Second, they maintain a level of virtual media communication that is significantly greater than weaker groups, especially in instant messaging, team discussion forum, and document sharing (differences are all statistically significant, see Table 4). It appears that planning — a phase that establishes membership responsibilities and task logistics-is a critical time when strong e-leaders emerge. Strong e-leaders maintain a higher-level contact in all categories with alternating use of virtual and traditional media with their group members.

The media use declines in the 3rd phase (execution) in all categories in all groups. Nevertheless, stronger e-leadership 
Table 5 Relationships between E-leadership and media use

\begin{tabular}{|c|c|c|c|c|c|c|}
\hline & & Face to face & Instant messaging & $\begin{array}{l}\text { Team discus- } \\
\text { sion forum }\end{array}$ & Document sharing & Presentation display \\
\hline \multicolumn{2}{|l|}{ E-trust $(1 / 1 / 1 / 1)^{\mathrm{a}}$} & $0.057^{\mathrm{b}}$ & $0.715^{* * *[0.009]}$ & $0.798 * * *[0.002]$ & $0.666^{* *[0.018]}$ & $0.568^{*[0.054]}$ \\
\hline \multicolumn{2}{|c|}{ E-communication (5/2/6/4) } & 0.016 & $0.638 * *[0.026]$ & $0.715^{* * *[0.009]}$ & $0.666^{* *[0.018]}$ & $0.592 * *[0.043]$ \\
\hline \multicolumn{2}{|l|}{ E-social (2/4/4/5) } & 0.023 & $0.720 * * *[0.008]$ & $0.783 * * *[0.003]$ & $0.724 * * *[0.008]$ & $0.602 * *[0.039]$ \\
\hline \multicolumn{2}{|l|}{ E-team (3/5/5/6) } & -0.128 & $0.594 * *[0.042]$ & $0.740 * * *[0.006]$ & $0.731 * * *[0.007]$ & $0.596^{* *[0.041]}$ \\
\hline \multicolumn{2}{|l|}{ E-change $(4 / 3 / 2 / 2)$} & -0.072 & $0.610 * *[0.035]$ & $0.736 * * *[0.006]$ & $0.707 * *[0.010]$ & $0.521 *[0.083]$ \\
\hline \multicolumn{2}{|l|}{ E-tech $(6 / 6 / 3 / 3)$} & -0.052 & $0.669 * *[0.017]$ & $0.755^{*} * *[0.005]$ & $0.736 * * *[0.006]$ & $0.521 *[0.083]$ \\
\hline \multirow{2}{*}{$\begin{array}{l}\text { E-leadership } \\
\text { (overall index) }\end{array}$} & & -0.026 & $0.673 * *[0.016]$ & $0.774 * * *[0.003]$ & $0.721 * * *[0.008]$ & $0.580 * *[0.048]$ \\
\hline & \multicolumn{2}{|c|}{ Social media } & Email & Telephone & $\begin{array}{l}\text { Hard copies of docu- } \\
\text { ments }\end{array}$ & Video conferencing \\
\hline E-trust $(1 / 1 / 1 / 1)^{\mathrm{a}}$ & \multicolumn{2}{|c|}{-0.229} & 0.121 & 0.317 & 0.308 & 0.343 \\
\hline $\begin{array}{l}\text { E-communication } \\
(5 / 2 / 6 / 4)\end{array}$ & \multicolumn{2}{|c|}{-0.066} & 0.103 & 0.288 & 0.309 & 0.380 \\
\hline E-social $(2 / 4 / 4 / 5)$ & \multicolumn{2}{|c|}{-0.072} & 0.157 & 0.325 & 0.324 & 0.455 \\
\hline E-team $(3 / 5 / 5 / 6)$ & \multicolumn{2}{|c|}{-0.190} & 0.169 & 0.279 & 0.373 & 0.483 \\
\hline E-change $(4 / 3 / 2 / 2)$ & \multicolumn{2}{|c|}{-0.217} & 0.171 & 0.245 & 0.334 & 0.435 \\
\hline E-tech $(6 / 6 / 3 / 3)$ & \multicolumn{2}{|c|}{-0.198} & 0.087 & 0.302 & 0.291 & 0.410 \\
\hline $\begin{array}{l}\text { E-leadership (overall } \\
\text { index) }\end{array}$ & \multicolumn{2}{|c|}{-0.171} & 0.139 & 0.299 & 0.331 & 0.426 \\
\hline
\end{tabular}

(a) In parentheses are rankings based on a 5-point scale index. 1 is the highest rank, 6 the lowest, in 4 phases of initiating, planning, executing, and closing. So the ranks of E-trust (1/1/1/1) show this e-leadership dimension ranks firsts in all 4 phases. (b) Shown are the results of the Pearson correlation coefficient $(r)$ test, averages in all four phases. In brackets are statistically significant results highlighted: $* p<.1 ; * * p<.05, * * *$ $p<.01$

teams maintain a higher-level communication than weaker teams in all categories, though these differences are not statistically significant. Then, in the closing stage, another major difference for stronger e-leadership groups surfaces with the resurgent usage of virtual media, which in the case of document sharing and presentation display was even stronger than the initiating phase. As in the planning phase, team discussion forum and document sharing stand out as two ICTs used significantly more by stronger e-leadership groups than weaker teams at the closing stage.

In sum, there is a U-shape pattern of ICT use in stronger e-leadership groups which suggests a greater need for intergroup communication at the planning and closing stages of a project. In contrast, weaker e-leadership groups experience declines in all media over time. The different utilization patterns of ICTs between stronger and weaker e-leadership groups in project phases are dramatic. This finding supports the literature that leadership is as much about sustaining the managerial (operational) process as about enhancing institutional outcomes [45, 65]. It indicates the importance of sustaining leadership efforts throughout the whole managerial and productional process in improving leadership effectiveness, which is particularly important in a project management setting of this study where timely completion of clearly-defined tasks for team members is the key for success.

Finding 3: E-trust is the most important e-leadership attribute in media use, and it is built largely through virtual ICT media, notably instant messaging, team discussion forum, document sharing, and presentation display.

We further analyze the relationship between six e-leadership components and ICT media use. Table 5 shows that, among all six e-leadership attributes, e-trust was ranked the highest in all 4 phases, reflecting the trust-building nature of project development where members are transient and responsibilities are relatively short-term but clearly-defined and demanding.

Trust is developed largely through 4 virtual ICTs in team discussion forum, instant messaging, document sharing, and presentation display. Strong leaders use rich media (team discussion forum and instant messaging) to build relationships, which are reinforced through lean media (document sharing and presentation display) to accomplish tasks. Table 5 shows that these 4 virtual ICTs are the 
most significant in developing e-leadership. All key leadership functions - trust development, communication, social activities, team building, change management, and technology sophistication-are associated with these 4 ICTs at statically significant levels. Indeed, essay responses indicate that group leaders often took responsibilities of assigning detailed tasks to group members. Earning trust through frequent ICT communications seem to help leaders accomplish that. Leaders use these 4 ICTs in communication with members and these media in turn help leaders build up their leadership functions.

\section{Discussion}

Although the cross-cutting nature of ICTs calls for sophisticated and specific ICT competencies of leaders, few studies have focused on leadership mediated by ICTs. Indeed, empirical studies on the relationship between ICTs and e-leadership are few. This study addresses this. In this section, we highlight the primary findings and offer interpretations.

First, though most leaders establish a pattern of ICT utilization early on in the project development, strong e-leaders maintain such utilization from the planning stage through the end of the project. Indeed, a key distinction of a strong leader from a weaker one is the ability to increase ICT use in planning and closing the project. A core of technology uses needs to be effective in trust building and relationship development perhaps in the early stages of project initiating and planning, which in turn provides amicable group dynamics for task-oriented responsibilities in the execution stage for the leader. In this research setting, these core media include combination uses of instant messaging, team discussion forums, document sharing, and presentation display.

Second, strong leaders use rich media (most notably discussion forum, and instant messaging to a certain degree) more often and consistently than lean media (e.g., presentation display). Rich media have better communication effects in conveying ambiguous information and become more effective for bonding, brainstorming, and rapid feedback loops which could be consistently beneficial for group communication. However, as time goes on, lean media (such as document sharing) play an increasingly important role as supplemental media in team communication. This observation is consistent with ICT Succession Theory which points out that strategic use of ICTs over time need supplementary modalities in order to improve efficiency and effectiveness [8, 42]. Indeed, an ICT strategy generally needs to involve complementary modalities to enhance effectiveness, in an evolving matter of events. This study provides empirical insights supporting this theoretical perspective in a virtual team setting which has seen flourishing research on teams' media use [32, 66] and leadership emergence [67, 68].More specifically, stronger e-leaders utilized rich media (mainly discussion forum and instant messaging) more for key communication and added supplementary lean media (document sharing and presentation display and hard copies) to maintain team members' contact for task follow-up. The implication is that e-leaders should be both consistent and flexible in their use of multiple ICTs.

Third, strong leaders focus on building trust with ICTs. By doing so, leaders provide an environment of institutional support needed to facilitate ICT adoption as suggested by the literature [69]. Strong e-leaders understand that trust and trust-building are key for effective leadership in a project managerial setting where members are transient and responsibilities are relatively short-term but clearly-defined and demanding. Effective ICT utilization is an essential part of trust-building throughout the project development process in which initial division of labor, changing responsibilities over time, and unexpected circumstances that require collaborative responses all pose challenges for the leader and test the need of members to trust the leader. Trust, as a social and relational construct, is perhaps better developed within an environment where leaders stress the use of rich media ICTs such intensive instant messages and discussions to help maintain a level of contact among team members. Yet the alternative use of lean and rich media ICTs throughout the process to maximize the effectiveness of overall communications is as important as "rich" communications. As a respondent said, "[our team leader] tried to use various media tools to communicate with members. [Consequently] Our division of labor is very clear, resulting in no dispute in the process of research and a relaxed and happy team atmosphere."

\section{Conclusion}

This study uses a field research methodology to examine the role of e-leadership in ICT utilization in a teamwork setting. We find that an effective e-leader should have a consistent level of ICT utilization throughout the project and alternate the uses of various ICT modalities in a trustbuilding process to accomplish team tasks. These findings can contribute to an emerging framework that views 
ICT-mediated leadership as an essential part of management and policy making.

Though the findings point to a set of general principles in leadership-ICT relationship, the application of these principles should be made in different team settings and e-leadership circumstances to improve the generalizability of the findings. For example, a larger team size (more than 4-5 members of this research) could make frequent team discussions more difficult to organize, so, instead of using discussion forum, a team leader could choose to use more interactive and engaging media such as video conference but with less utilization frequencies. Moreover, projects could have various durations, which suggest different ways for the leader to maximize communication effectiveness. Indeed, a project on a short notice for a quick result often requires group members to reach a certain level of familiarity with the issue before moving forward, which suggests intensive rich media communication from the leader before assigning the responsibilities-a usage pattern different from the present research with task responsibilities more evenly spreading over a relatively long period. Furthermore, the nature of the team projects in this researchacademic works supervised by professors-suggest that students can always talk to their supervisor rather than group leaders. This additional layer of communication may influence e-leadership and the media usage patterns observed in this research.

The limitations of this research also include its exploratory nature with a case study method that focuses on a small sample. This study belongs to a genre of research on small-team performance which mainly uses the case study method with data from small groups to build empirical evidence. The specific setting of the study (college graduate students) on a limited sample indicates a need to extend the research into other settings with larger sample sizes. Future research is needed to further advance interpretations, such as in studies with settings involving broader institutional contexts and country contexts for better implications, or comparative studies involving multiple nations. Lack of video conference equipment at the time of this research limits its applicability to Covid 19 which saw heavy use of video conference tools (e.g., Zoom). Moreover, media use is measured by an ordinal variable, which limits the accuracy in measuring the usage pattern. Project outcomes (student grade) could be assessed with more objective measures such as blind reviews. Future efforts should be made to improve these aspects of the research in improving the validity and generalizability of the results. Despite of these limitations, the study reveals the potency and intricacy of the relationship between leadership and
ICT utilization that is at the heart of the digital revolution and becomes even more critical during emergencies. ${ }^{1}$

\section{Appendix A: Concepts, Definitions, and Measurement}

(All measurement instruments are provided upon request)

\begin{tabular}{lll}
\hline Concepts & Definitions & Measurements \\
\hline ICT utilization (Use) & $\begin{array}{l}\text { The level of utilizing } \\
\text { information com- } \\
\text { munication tech- } \\
\text { nologies (ICTs) at } \\
\text { the team level—an } \\
\text { advancement of } \\
\text { ICT use from } \\
\text { initial adoption and } \\
\text { at the individual } \\
\text { level }\end{array}$ & $\begin{array}{l}\text { The frequencies of } \\
\text { using nine ICTs } \\
\text { and face-to-face: } \\
\text { Instant messaging, } \\
\text { team discussion } \\
\text { platform, document } \\
\text { sharing, presentation } \\
\text { display, hard copies, } \\
\text { email, social media, } \\
\text { telephone, and video } \\
\end{array}$ \\
& $\begin{array}{l}\text { conferencing, at the } \\
\text { measurement levels } \\
\text { of Never, less than 1 } \\
\text { times weekly, 1 to 2 }\end{array}$ \\
& & times weekly, 3 to 4 \\
& & times weekly, 5 to 6 \\
& & times weekly, more \\
& & \\
& &
\end{tabular}

\footnotetext{
${ }^{1}$ In this research, we also examined the relationship between e-leadership and team dynamics and project outcomes. The results show that there is little evidence that e-leadership directly affects project outcomes. However, there is some evidence that e-leadership is related to the team dynamic process. In the analysis, we explore how leadership activities, mediated through various ICTs, may influence (a) the group project grade as team outcomes, and (b) an intermediate variable - a measure of the group dynamics, processes, and operations leading to team outcomes. Our results show that no correlation is found between e-leadership and project grades. However, the team dynamic variable is related to e-leadership. The correlation between e-leadership and team dynamics (aggregate) is at .604 (the correlation coefficient), statistically significant at the .05 level. These results suggest that while there is no evidence e-leadership directly influences group outcomes, it may nonetheless affect the group process and operations, which could suggest an indirect relationship with project outcomes. Notice that this result comes from a bivariate analysis without control of potential confounding variables such as student ability and academic background. However, the result is consistent with the literature that leadership activities affect institution-level outcome through managerial processes,suggesting a direction for future studies.
} 


\begin{tabular}{|c|c|c|}
\hline Concepts & Definitions & Measurements \\
\hline $\begin{array}{l}\text { E-leadership (compe- } \\
\text { tencies) }\end{array}$ & $\begin{array}{l}\text { An ICT-mediated } \\
\text { social influence } \\
\text { process intended to } \\
\text { change attitudes, } \\
\text { feelings, think- } \\
\text { ing, behavior, } \\
\text { and performance, } \\
\text { based on a leader's } \\
\text { ability (compe- } \\
\text { tency) to com- } \\
\text { municate clearly } \\
\text { and appropriately, } \\
\text { provide adequate } \\
\text { social interac- } \\
\text { tion, inspire and } \\
\text { manage change, } \\
\text { build and hold } \\
\text { teams account- } \\
\text { able, demonstrate } \\
\text { technological kno- } \\
\text { whow related to } \\
\text { ICTs, and develop } \\
\text { a sense of trust in } \\
\text { virtual environ- } \\
\text { ments [54, 53] }\end{array}$ & $\begin{array}{l}\text { This study adopts } \\
\text { the measurement } \\
\text { system used by } \\
\text { Van Wart et al. [53] } \\
\text { and Roman et al. } \\
\text { [54] that classifies } \\
\text { e-leadership into the } \\
\text { six competencies of } \\
\text { e-communication, } \\
\text { e-social skill, } \\
\text { e-change manage- } \\
\text { ment, e-team skills, } \\
\text { e-tech savvy, and } \\
\text { e-trustworthiness }\end{array}$ \\
\hline
\end{tabular}

A total of 69 items

were used to measure the six e-leadership competencies, as suggested by Van Wart et al. [53]: e-communication 15 items, e-social 11 items, e-change 12 items, e-team 10 items, e-tech 8 items, and e-trust 13 items. For example, in measuring e-communication, a respondent was asked to assess the item "In virtual communication, the leader is clear and does not create misunderstandings among the team."

The e-leadership measurement was taken in all 4 phases of the project, and the average Cronbach alphas are $0.925,0.906$, 0.913, 0.930, 0.925, 0.965 for e-communication, e-social, e-change, e-team, e-tech, and e-trust, respectively

\begin{tabular}{|c|c|c|}
\hline Concepts & Definitions & Measurements \\
\hline Team dynamics & $\begin{array}{l}\text { This is a measure- } \\
\text { ment of group } \\
\text { process in terms } \\
\text { of how the team } \\
\text { was conducting } \\
\text { its activities in six } \\
\text { aspects of 'leader- } \\
\text { ship and direction,' } \\
\text { 'organization and } \\
\text { management,' } \\
\text { 'ideas and sug- } \\
\text { gestions,' 'data } \\
\text { collection,' 'data } \\
\text { analysis,' and } \\
\text { 'report writing.' } \\
\text { The measure } \\
\text { reflects the highly } \\
\text { interactive process } \\
\text { often observed in } \\
\text { project manage- } \\
\text { ment }\end{array}$ & $\begin{array}{l}\text { Each student was } \\
\text { required to grade } \\
\text { their team member } \\
\text { as 'major contri- } \\
\text { bution,' 'some } \\
\text { contribution,' and } \\
\text { 'little contribution,' } \\
\text { and assign proper } \\
\text { distribution of points }\end{array}$ \\
\hline Project outcomes & $\begin{array}{l}\text { Completion and } \\
\text { quality of the } \\
\text { project }\end{array}$ & $\begin{array}{l}\text { Projects are graded on } \\
\text { a } 100 \text {-point scale and } \\
\text { converted to letter } \\
\text { grades (i.e., A, B, C, } \\
\text { D, F) }\end{array}$ \\
\hline Interviews & $\begin{array}{l}\text { To solicit additional } \\
\text { feedback from stu- } \\
\text { dents to understand } \\
\text { e-leadership and } \\
\text { ICT use in their } \\
\text { project making } \\
\text { process }\end{array}$ & $\begin{array}{l}\text { Open-ended questions } \\
\text { were developed to } \\
\text { ask students describ- } \\
\text { ing the experience } \\
\text { and lessons of work- } \\
\text { ing on the project, } \\
\text { with questions such } \\
\text { as "What were } \\
\text { the critical learn- } \\
\text { ing events you and } \\
\text { your groupmates } \\
\text { experienced? What } \\
\text { were the critical } \\
\text { stages in project } \\
\text { development? What } \\
\text { difficulties did you } \\
\text { experience? How did } \\
\text { you overcome any } \\
\text { difficulties? What } \\
\text { was your experience } \\
\text { of leading the team, } \\
\text { membership of the } \\
\text { team? etc." }\end{array}$ \\
\hline
\end{tabular}




\section{Appendix B: Project phases}

\begin{tabular}{|c|c|c|}
\hline Phase & Period & Tasks \\
\hline Initiating & Weeks 1 and 2 & $\begin{array}{l}\text { 1. Determining how } \\
\text { reliable other group } \\
\text { members are } \\
\text { 2. Determining what } \\
\text { information is needed } \\
\text { and others have } \\
\text { 3. Determining the best } \\
\text { way to relay information } \\
\text { 4. Assessing opportuni- } \\
\text { ties for delegation of } \\
\text { responsibilities } \\
\text { 5. Balancing responsibili- } \\
\text { ties and authority } \\
\text { 6. Specifying conditions } \\
\text { for delegating }\end{array}$ \\
\hline Planning & Weeks 3 to 6 & $\begin{array}{l}\text { 1. Reaching consensus on } \\
\text { job goals, timeline, and } \\
\text { work procedure } \\
\text { 2. Explaining the } \\
\text { complexity of the task } \\
\text { involved } \\
\text { 3. Defining individual } \\
\text { members' job responsi- } \\
\text { bilities } \\
\text { 4. Establishing priorities } \\
\text { among job responsibili- } \\
\text { ties } \\
\text { 5. Setting goals for each } \\
\text { priority area } \\
\text { 6. Setting performance } \\
\text { standards } \\
\text { 7. Motivating project } \\
\text { members to buy into } \\
\text { their responsibilities } \\
\text { 8. Requiring collaboration } \\
\text { from project members } \\
\text { 9. Identifying the type of } \\
\text { action planning neces- } \\
\text { sary } \\
\text { 10. Determining the } \\
\text { logistics that need to be } \\
\text { planned } \\
\text { 11. Consulting and } \\
\text { coordinating to ensure } \\
\text { planning accuracy and } \\
\text { buy-in } \\
\text { 12. Defining and measur- } \\
\text { ing key indicators of } \\
\text { progress and perfor- } \\
\text { mance }\end{array}$ \\
\hline
\end{tabular}

\begin{tabular}{|c|c|c|}
\hline Phase & Period & Tasks \\
\hline$\overline{\text { Executing }}$ & Weeks 7 to 25 & $\begin{array}{l}\text { 1. Assembling project } \\
\text { capacities in resources, } \\
\text { technologies, and infor- } \\
\text { mation } \\
\text { 2. Comparing progress } \\
\text { with plans } \\
\text { 3. Resolving problems } \\
\text { and issues that hinder } \\
\text { the execution of the } \\
\text { project } \\
\text { 4. Maintaining a variety } \\
\text { of sources of informa- } \\
\text { tion } \\
\text { 5. Creating an envi- } \\
\text { ronment that fosters } \\
\text { learning, flexibility, and } \\
\text { change } \\
\text { 6. Encouraging a mindset } \\
\text { that will foster high- } \\
\text { quality change and } \\
\text { innovative learning } \\
\text { 7. Providing the tools and } \\
\text { opportunities for learn- } \\
\text { ing and innovation } \\
\text { 8. Generating options and } \\
\text { choosing an option } \\
\text { 9. Motivating project } \\
\text { members to fulfill their } \\
\text { responsibilities } \\
\text { 10. Alleviating or } \\
\text { avoiding the free rider } \\
\text { problem } \\
\text { 11. Conducting review } \\
\text { meetings } \\
\text { 12. Identifying and clas- } \\
\text { sifying problems in } \\
\text { implementation } \\
\text { 13. Analyzing difficult } \\
\text { problems } \\
\text { 14. Asking and clarifying } \\
\text { questions } \\
\text { 15. Encouraging open and } \\
\text { honest reporting }\end{array}$ \\
\hline Closing & Weeks 26 to 30 & $\begin{array}{l}\text { 1. Assembling the sepa- } \\
\text { rate parts of the project } \\
\text { to form a holistic prod- } \\
\text { uct (the project report) } \\
\text { 2. Maintaining a high } \\
\text { level of quality for the } \\
\text { project report } \\
\text { 3. Ensuring on-time sub- } \\
\text { mission of the project } \\
\text { report (timeliness) } \\
\text { 4. Ensuring any follow-up } \\
\text { communications after } \\
\text { the submission }\end{array}$ \\
\hline
\end{tabular}


Supplementary Information The online version contains supplementary material available at https://doi.org/10.1007/s10799-021-00354-4.

\section{References}

1. Avolio BJ, Kahai S, Dodge GE (2001) E-leadership: implications for theory, research, and practice. Leadersh Q 11(4):615-668

2. Avolio BJ, Kahai SS (2003) Adding the "E" to E-leadership. Organ Dyn 31:325-338

3. Avolio BJ, Sosik JJ, Kahai SS, Baker B (2014) E-leadership: re-examining transformations in leadership source and transmission. Leadersh Q 25(1):105-131

4. Hambley LA, O'Neill TA, Kline T (2007) Virtual team leadership: the effects of leadership style and communication medium on team interaction styles and outcomes. Organ Behav Hum Decis Process 103(1):1-20

5. Mesmer-Magnus JR, DeChurch L, Jimenez-Rodriguez M, Wildman J, Shuffler M (2011) A meta-analytic investigation of virtuality and information sharing in teams. Organ Behav Hum Decis Process 115(2):214-225

6. Newton L (2003) Management and the use of ICT in subject teaching. In: IFIP conference on information technology in educational management. Springer, Boston, MA, pp 11-20

7. Sanaei MR, Sobhani FM (2018) Information technology and e-business marketing strategy. Inf Technol Manag 19(3):185-196

8. Stephens KK, Rains SA (2011) Information and communication technology sequences and message repetition in interpersonal interaction. Commun Res 38(1):101-122

9. Jablokow KW, Jablokow AG, Seasock CT (2010) IT leadership from a problem solving perspective. Inf Technol Manag 11(3):107-122

10. Ishak AW, Ballard D (2012) Time to re-group: a typology and nested phase model for action teams. Small Group Res 43(1):3-29

11. McGrath JE (1991) Time, interaction, and performance (TIP): a theory of groups. Small Group Res 22(2):147-174

12. McGrath J, Arrow H, Berdahl J (2000) The study of groups: past, present, and future. Pers Soc Psychol Rev 4(1):95-105

13. Starling G (2011) Managing the public sector. Ninth edition. Wadsworth, Boston

14. Garvin C (2008) Project program development and implementation. Small Group Res 39(1):60-81

15. Katzenbach JR, Smith DK (1993) The Wisdom of teams: creating the high-performance organization. Harvard Business Review Press, Boston

16. Fussell S, Kraut R, Lerch FJ, Scherlis W, McNally M, Cadiz J (1998) Coordination, overload and team performance: effects of team communication strategies. In: Proceedings of the 1998 ACM conference on computer supported cooperative work, pp 275-284

17. Druskat VU, Kayes DC (2000) Learning versus performance in short-term project teams. Small Group Res 31(3):328-353

18. Guenter H, Gardner WL, McCauley KD, Randolph-Seng B, Prabhu V (2017) Shared authentic leadership in research teams: testing a multiple mediation model. Small Group Res 48(6):719-765

19. McGregor D (1960) The human side of enterprise. McGrawHill, New York

20. Purvanova RK (2013) The role of feeling known for team member outcomes in project teams. Small Group Res 44(3):298-331

21. Lehmann-Willenbrock N, Meinecke AL, Rowold J, Kauffeld S (2015) How transformational leadership works during team interactions: a behavioral process analysis. Leadersh Q 26(6):1017-1033
22. Richter AW, Dawson JF, West MA (2011) The effectiveness of teams in organizations: a meta-analysis. Int J Hum Resour Manag 22(13):2749-2769

23. Salas E, Shuffler ML, Thayer AL, Bedwell WL, Lazzara EH (2015) Understanding and improving teamwork in organizations: a scientifically based practical guide. Hum Resour Manag 54(4):599-622

24. Lee SH, Leem CS, Bae DJ (2018) The impact of technology capability, human resources, internationalization, market resources, and customer satisfaction on annual sales growth rates of Korean software firms. Inf Technol Manag 19(3):171-184

25. Scholtes PR, Joiner BL, Streibel BJ (2003) The team handbook. Madison, WI: Straus Printing Company

26. Prichard JS, Bizo LA, Stratford RJ (2011) Evaluating the effects of team-skills training on subjective workload. Learn Instr 21(3):429-440

27. Grossman R, Feitosa F (2018) Team trust over time: modeling reciprocal and contextual influences in action teams. Hum Resour Manag Rev 28(4):395-410

28. Erhardt N, Gibbs J, Martin-Rios C, Sherblom J (2016) Exploring affordances of email for team learning over time. Small Group Res 47(3):243-278

29. McLeod PL (2013) Distributed people and distributed information: vigilant decision-making in virtual teams. Small Group Res 44(6):627-657

30. Bergiel BJ, Bergiel EB, Balsmeier PW (2008) Nature of virtual teams: a summary of their advantages and disadvantages. Manag Res News 31(2):99-110

31. Straube J, Meinecke AL, Schneider K, Kauffeld S (2018) Effects of media compensation on team performance: the role of demographic faultlines. Small Group Res 49(6):684-722

32. Rasters G, Vissers G, Dankbaar B (2002) An inside look: rich communication through lean media in a virtual research team. Small Group Res 33(6):718-754

33. Hambley LA, O'Neill TA, Kline T (2007) Virtual team leadership: perspectives from the field. $\mathrm{IJeC} 3(1): 40-64$

34. Hoyt C, Blascovich J (2003) Transformational and transactional leadership in virtual and physical environments. Small Group Res 34(6):678-715

35. Gilson LL, Maynard MT, Bergiel EB (2013) Virtual team effectiveness: an experiential activity. Small Group Res 44(4):412-427

36. Staples DS, Webster J (2007) Exploring traditional and virtual team members' "best practices": a social cognitive theory perspective. Small Group Res 38(1):60-97

37. Arrow H, McGrath JE, Berdahl JL (2000) Small groups as complex systems: formation, coordination, development, and adaptation. Sage Publications, Thousand Oaks

38. Handke L, Schulte EM, Schneider K, Kauffeld S (2019) Teams, time, and technology: variations of media use over project phases. Small Group Res 50(2):266-305

39. Stephens KK (2007) The successive use of information and communication technologies at work. Commun Theory 17:486-507

40. Delice F, Rousseau M, Feitosa J (2019) Advancing teams research: what, when, and how to measure team dynamics over time. Front Psychol 10:1324

41. Mohammed S, Alipour K (2014) It's time for temporal leadership: individual, dyadic, team, and organizational effects. Ind Organ Psychol 7(2):178-182

42. Stephens KK, Sornes JO, Rice RE, Browning LD, Saetre AS (2008) Discrete, sequential, and follow-up use of information and communication technology by experienced ICT users. Manag Commun Q 22(2):197-231

43. Ramos-Villagrasa PJ, Marques-Quinteiro P, Navarro J, Rico R (2018) Teams as complex adaptive systems: reviewing 17 years of research. Small Group Res 49(2):135-176 
44. Koeslag-Kreunen M, Van den Bossche P, Hoven M, Van der Klink M, Gijselaers W (2018) When leadership powers team learning: a meta-analysis. Small Group Res 49(4):475-513

45. Wang X, Van Wart M, Lebredo N (2014) Sustainability leadership in a local government context. Public Perform Manag Rev 34(3):339-364

46. Beck SJ, Keyton J (2013) Team cognition, communication, and message interdependence. In: Salas et al (eds) Theories of team cognition. Routledge, Abingdon-on-Thames, pp 497-520

47. Bélanger F, Watson-Manheim MB (2006) Virtual teams and multiple media: structuring media use to attain strategic goals. Group Decis Negot 15(4):299-321

48. Dennis AR, Fuller RM, Valacich J (2008) Media, tasks, and communication processes: a theory of media synchronicity. MIS Q 32(3):575-600

49. Shachaf P, Hara N (2007) Behavioral complexity theory and media selection: a proposed theory for global virtual teams. J Inf Sci 33(1):63-75

50. Watson-Manheim MB, Bélanger F (2007) Communication media repertoires: dealing with multiplicity of media choices. MIS Q 31(2):267-293

51. Raes E, Kyndt E, Dochy F (2015) Turning points during the life of student project teams: a qualitative study. Front Learn Res 3(2):63-89

52. Van Wart M, Roman A, Wang X, Liu C (2017) Integrating ICT adoption issues into (e-) leadership theory. Telemat Inform 34(5):527-537

53. Van Wart M, Roman A, Wang X, Liu C (2017) Operationalizing the definition of e-leadership: identifying the elements of e-leadership. Int Rev Adm Sci 85(1):80-97

54. Roman AV, Van Wart M, Wang X, Liu C, Kim S, McCarthy A (2019) Defining e-leadership as competence in ICT-mediated communications: an exploratory assessment. Public Adm Rev 79(6):853-866

55. Nardi BA, Whittaker S (2002) The place of face-to-face communication in distributed work. In: Hinds P, Kiesler SB, Kiesler S (eds) Distributed work. MIT Press, Cambridge, pp 83-110

56. DeSanctis G, Poole MS (1992) Capturing the complexity in advanced technology use: adaptive structuration theory. Organ Sci 5(2):121-147
57. Orlikowski WJ (1992) The duality of technology: rethinking the concept of technology in organizations. Organ Sci 3(3):398-427

58. Hilbert M, Lopez P (2011) The world's technological capacity to store, communicate, and compute information. Science 332(6025):60-65

59. Babbie ER (2011) Introduction to social research. Wadsworth Cengage Learning, Boston

60. Rusticus SA, Justus BJ (2019) Comparing student- and teacherformed teams on group dynamics, satisfaction, and performance. Small Group Res 50(4):443-457

61. Van Wart M (2012) Leadership in public organizations: an introduction, 2nd edn. M.E Sharpe, New York

62. Contreras F, Baykal E, Abid G (2020) E-leadership and teleworking in times of COVID-19 and beyond: what we know and where do we go. Front Psychol 11:3484

63. Torre T, Sarti D (2020) The "way" toward E-leadership: some evidence from the field. Front Psychol 11:2753

64. Bell BS, Kozlowski SW (2002) A typology of virtual teams: Implications for effective leadership. Group Organ Manag 27(1):14-49

65. Hunsaker PL, Hunsaker JS (2008) Virtual teams: a leader's guide. Team Perform Manag 14:86-101

66. Graetz KA, Boyle ES, Kimble CE, Thompson P, Garloch JL (1998) Information sharing in face-to-face, teleconferencing, and electronic chat groups. Small Group Res 29(6):714-743

67. Balthazard PA, Waldman DA, Warren JE (2009) Predictors of the emergence of transformational leadership in virtual decision teams. Leadersh Q 20(5):651-663

68. Wilson JM, Fletcher TD, Pescosolido T, Major DA (2021) Extraversion and leadership emergence: differences in virtual and faceto-face teams. Small Group Res 52(5):535-564

69. Venkatesh V, Morris M, Davis G, Davis F (2003) User acceptance of information technology: toward a unified view. MIS Q 27(3):425-478

Publisher's Note Springer Nature remains neutral with regard to jurisdictional claims in published maps and institutional affiliations. 